Diabetologia (1996) 39: 206-211

\title{
Rapid formation of capillary endothelial cells in rat skeletal muscle after exposure to insulin
}

\author{
A. Holmäng ${ }^{1}$, E.Jennische ${ }^{2}$, P. Björntorp \\ ${ }^{1}$ The Wallenberg Laboratory, Department of Heart and Lung Diseases, Sahlgrenska University Hospital, Göteborg, Sweden \\ ${ }^{2}$ Department of Anatomy and Cell Biology, University of Göteborg, Sweden
}

Summary Research has suggested a role for insulin delivery through capillaries in muscle in the regulation of insulin sensitivity. Therefore, the formation and turn-over of capillary endothelial cells in muscle were studied in relation to exposure to moderately elevated insulin concentrations with or without concomitant increase of corticosterone concentrations. Female rats were exposed to a moderate, physiological hyperinsulinaemia $(\sim 450 \mathrm{pmol} / \mathrm{l})$ for $24 \mathrm{~h} 48 \mathrm{~h}$, 3 days, 7 days and 7 weeks. Propranolol was used to inhibit elevated adrenergic activity. In one insulin-exposed group, corticosterone secretion was controlled by adrenalectomy with substitution of corticosterone to maintain normal concentrations, while another group was left with adrenal corticosterone secretion intact. Rats were exposed to insulin with controlled, non-elevated corticosterone concentrations after adrenalectomy and corticosterone substitution; compared to controls, the number of mitoses in capillary endothelial cells in the soleus and extensor digitorum longus muscle were approximately doubled after $24 \mathrm{~h}$, reaching a maximum, about fivefold higher than controls, after 3 days. After 7 weeks of insulin exposure there were no longer any significant differ- ences between control and insulin-exposed rats. The number of capillaries per unit muscle surface area was moderately (10-15\%) but significantly increased at 7 days (only the extensor digitorum longus muscle) and 7 weeks (the extensor digitorum longus and the soleus muscles). In rats exposed to insulin, with intact adrenals, endogenous corticosterone production resulted in concentrations about threefold higher than in rats adrenalectomized with subsequent corticosterone substitution. In these rats the increase in mitoses in capillary endothelium was totally abolished. The results of this study suggest that exposure to insulin in this rat model is followed by a dramatic shortterm increase in the formation of new capillary endothelial cells in muscle. It is also suggested that this growth factor-like effect of insulin is abolished by corticosterone. It is suggested that insulin and corticosterone exert opposite effects on the capillary network in muscles, which might be important for the insulin supply to this tissue, and hence for regulation of insulin sensitivity. [Diabetologia (1996) 39: 206-211]

Key words Muscle, hyperinsulinaemia, capillary endothelium, glucocorticoids.
Diminished insulin efficiency (insulin resistance) is considered to be a determinant for non-insulin-dependent diabetes mellitus as well as other prevalent

Received: 22 June 1995 and in revised form: 15September 1995

Corresponding author: Dr. A. Holmäng, The Wallenberg Laboratory, Sahlgrenska Hospital, S-41345 Göteborg, Sweden Abbreviations: IGF-1, Insulin-like growth-factor-1; BrdU, bromodeoxyuridine. diseases such as hypertension and cardiovascular disease [1]. Several studies have indicated a close statistical relationship between insulin resistance and low capillary density in muscle, and muscle tissue has been considered to be a major regulator of systemic glucose homeostasis [2-5].

Elevated circulating concentrations of glucocorticoids and androgens are followed by muscular insulin resistance [5-10]. This is paralleled by a decreased density of capillaries in muscle, as well as an apparent decrease of insulin effects on glucose metabolism at 
the level of the muscle cell $[5,10]$. These conditions are followed by hyperinsulinaemia, presumably a compensatory phenomenon $[5,6,10]$. In contrast, exposure to elevated insulin concentrations alone with control of hormones which antagonize insulin effects, is followed by elevated muscular capillarization, and, in this model, an apparently parallel insulin sensitivity [11].

These observations suggest that the balance between the effects of insulin and hormones with antiinsulin effects in muscle may be regulated at several levels, including capillary density, because previous and recent [12-16] research has indicated that binding of insulin to capillary endothelium and subsequent transcapillary transport may be important, rate-limiting steps for the cellular actions of insulin. Consequently, mechanisms regulating capillary surface area and transport rate through capillary endothelial cells might partly explain the action of insulin on target cells.

The previous observations indicate that insulin exposure by itself is followed by increased capillary density in muscle $[11,12]$ while glucocorticoids and androgens in excess, followed by insulin resistance have an opposite effect in spite of accompanying hyperinsulinaemia $[3,5,8,10]$. These findings suggest that insulin and hormones with anti-insulin effects might balance muscular capillary density and thereby provide a regulatory mechanism for insulin sensitivity of muscle tissue.

In order to attempt to elucidate this question, the present study was performed, in which the effects of insulin with or without compensatory endogenous elevation of glucocorticoid concentrations were followed. By examining both the rate of formation of new capillary endothelial cells and the resulting total number of capillaries in muscle, information was obtained on the effects on capillary turn-over. The results show dramatic, early effects of insulin on the formation of new capillary endothelial cells in muscle which later levels off, resulting in a moderate net increase in capillary density. The formation of new endothelial cells after insulin exposure was totally prevented when endogenous corticosterone concentrations were elevated.

\section{Materials and methods}

Female Sprague-Dawley rats (Alab, Stockholm, Sweden) weighing $196 \pm 11 \mathrm{~g}$ (mean $\pm \mathrm{SEM}$ ) were used for the experiments. They were housed in single cages at $23^{\circ} \mathrm{C}$ and fed commercial rat chow, containing $22 \%$ protein, $5 \%$ fat, and $51.5 \%$ carbohydrate, and sufficient minerals and vitamins (Ewos, Södertälje, Sweden), and tap water ad libitum. The dark:light cycle was $12: 12 \mathrm{~h}$, and the rats were kept under these conditions for at least 1 week before experiments.

Experimental groups. Three groups of rats were included in the study: 1) control rats infused with iso-osmotic saline 2) rats treated with insulin and propranolol (intact, insulin-exposed rats) 3) rats treated with insulin and propranolol, adrenalectomized and given corticosterone substitution (insulin-exposed rats given controlled corticosteroids).

Exposure to chronically elevated levels of insulin was accomplished by subcutaneous implantation of osmotic minipumps under diethyl ether anaesthesia (Alzet 2001; Alza Corporation, Palo Alto, Calif., USA). U-400 human insulin was used (Hoe 21 PH; Hoechst AG, Frankfurt am Main, Germany; kindly provided by Mr. M.Zoltobrocki) and 2 units of the hormone was delivered per day at a rate of $1 \mu \mathrm{l} / \mathrm{h}$ (after dilution in $0.9 \%$ saline) for $24 \mathrm{~h}, 48 \mathrm{~h}, 3$ days, 7 days and 7 weeks. Another minipump delivered propranolol, a $\beta$-receptor antagonist (Inderal; ICI, $\mathbf{Q}=$ cheshire, UK) to control $\beta$-adrenergic receptor activity as described previously [11]. Compensatory elevation of glucocorticoid secretion was prevented in one group by adrenalectomy [17]. After adrenal surgery, the rats were provided with a solution of corticosterone $(25 \mu \mathrm{g} / \mathrm{ml})$, $0.9 \% \mathrm{NaCl}$ and $0.2 \%$ ethanol in the drinking water [18], while one group was left with intact adrenals. Controls were treated with saline from minipumps. At the end of the experimental periods bromodeoxyuridine (BrdU) (Sigma, St. Louis, Mo., USA) was injected i.p. $(50 \mathrm{mg} / \mathrm{kg})$ and the animals were killed after $2 \mathrm{~h}$ with an overdose of pentobarbital, after which the soleus and extensor digitorum longus muscles were rapidly removed and frozen in liquid nitrogen. These muscles were selected because of their dense capillary network $[5,11]$.

\section{Histochemical examinations}

Number of replicating cells. BrdU is incorporated in the duplicating DNA during the S-phase of the cell cycle and BrdU-incorporation can be used to calculate the number of replicating cells [19]. The nuclei which had incorporated BrdU were visualized in tissue sections by immunohistochemistry. Serial transverse cryostat sections $(6 \mu \mathrm{m})$ were made from the soleus muscle. The cryosections were prepared and fixed for $5 \mathrm{~min}$ in cold methanol. After drying, the sections were treated with $70 \%$ formamide at $70^{\circ} \mathrm{C}$. The sections were then incubated with a monoclonal antibody (DAKO, Copenhagen, Denmark) against BrdU, followed by a rabbit anti-mouse antibody conjugated to alkaline phosphatase according to the manufacturer's instructions (DAKO). The sections were then developed for $30 \mathrm{~min}$ in a substrate solution containing nitro-blue-tetrazolium and X-phosphate (Boehringer Mannheim, Mannheim, Germany) in Tris-buffer at $\mathrm{pH}$ 9.5. Levamisole, $1 \mathrm{mmol} / \mathrm{l}$, was included to inhibit endogenous alkaline phosphatases. Finally the sections were rinsed and mounted in gelatine/glycerol. The number of BrdU-positive cells were counted in the microscope using a $10 \times$ objective. The sections were projected on a video screen and the number of positive cells per field were counted. At least five fields were counted in each section by two independent investigators. The mean was calculated and expressed as the number of positive cells per square millimetre.

Capillary density. The capillary network was visualized by staining tissue sections for alkaline phosphatase. Six-micronthick cryosections were prepared and fixed for $5 \mathrm{~min}$ in methanol. After drying, the sections were incubated for $30 \mathrm{~min}$ with the substrate solution mentioned above, but without levamisol. The sections were then rinsed and mounted in gelatin/glycerol. The number of mitoses and capillaries per square millimetre was calculated by a digitizer table connected to a computer with a specially developed program. 
Plasma analyses. Blood samples for determinations of plasma insulin, glucose and corticosterone were collected during the treatment from a nick in the tail of each rat. Plasma glucose was measured with a glucose oxidase method with a Beckman glucose analyser 2 (Beckman, Palo Alto, CA). Insulin concentration was measured with a double antibody radioimmunoassay (Pharmacia, Uppsala, Sweden). Plasma corticosterone was determined in plasma by a commercially available method for radioimmunoassay (ICN Biomedicals, Carson, Calif., USA). Insulin-like growth factor 1 (IGF-I) was measured by an immunoradiometric assay after formic acid-ethanol extraction (Byk, Sangtec Diagnostica GmbH, Dietzenbach, Germany).

The study was approved by the animal ethics committee of the University of Göteborg.

\section{Statistical analyses}

Statistical methods used were Student's $t$-test and, when several comparisons were performed, analysis of variance, utilizing the STAT-View program of the Macintosh system.

\section{Results}

Table 1 shows the changes in body weight during the experimental period. In comparisons with controls, insulin-exposed rats showed an increase in weight which was noted after $48 \mathrm{~h}$.

Plasma glucose was significantly lower in the insulinized, adrenalectomized-corticosterone substituted rats than in controls, and plasma insulin was elevated in both insulin-exposed groups (Table 1).

Compared with controls the corticosterone concentrations after $24 \mathrm{~h}$ were significantly lower in the insulinized, adrenalectomized-corticosterone substituted rats while in the group with intact adrenals the values were higher. This pattern was repeated after $48 \mathrm{~h}, 3$ days and 7 days. The IGF-I concentrations were lower in the insulinized, adrenalectomized-corticosterone substituted rats than in controls but not in the insulinized group with intact adrenals after 7 days (Table 2).

In sections incubated with the BrdU-antibody, stained cells, indicating replicating cells, were seen between the muscle fibers, whereas no positive cells were seen within the muscle fibers (Fig. 1). In control rats only a few replicating cells were seen (Fig. $1 \mathrm{a}$ ). In rats exposed to insulin (insulinized, adrenalectomized-corticosterone substituted group) there was a markedly higher number of replicating cells (Fig. 1b). Figure 1c shows the localization of the mitoses to capillary endothelial cells.

The number of replicating cells in capillary endothelium was then quantitated at different time points. A significant increase was observed after $24 \mathrm{~h}$ of insulin exposure in the insulinized, adrenalectomized-corticosterone substituted group in both the soleus (Fig.2), and the extensor digitorum longus muscle (Fig. 3) compared to the control rats. A further
Table 1. Insulin, glucose concentrations in plasma and increase of body weights after 24 h, 48 h, 3 days and 7 days of insulin exposure compared to control rats

\begin{tabular}{|c|c|c|c|}
\hline & $\begin{array}{c}\text { Control } \\
(n=10)\end{array}$ & $\begin{array}{l}\text { Insulin- and pro- } \\
\text { pranolol-treated } \\
\text { rats, adrenalecto- } \\
\text { mized and sub- } \\
\text { stituted with cor- } \\
\text { ticosterone } \\
(n=9)\end{array}$ & $\begin{array}{l}\text { Insulin- and } \\
\text { propranolol- } \\
\text { treated rats } \\
(n=5)\end{array}$ \\
\hline \multicolumn{4}{|c|}{ Glucose $(\mathrm{mmol} / \mathrm{l})$} \\
\hline $24 \mathrm{~h}$ & $5.1 \pm 0.4$ & $2.9 \pm 0.6^{b}$ & $5.5 \pm 0.6$ \\
\hline $48 \mathrm{~h}$ & $5.4 \pm 0.6$ & $3.4 \pm 0.7^{\mathrm{a}}$ & $5.7 \pm 0.6$ \\
\hline 3 days & $6.3 \pm 0.5$ & $4.6 \pm 0.5^{\mathrm{a}}$ & $6.8 \pm 0.7$ \\
\hline 7 days & $6.1 \pm 0.8$ & $4.7 \pm 0.3^{b}$ & $6.6 \pm 0.4$ \\
\hline \multicolumn{4}{|c|}{ Insulin (pmoll) } \\
\hline $24 \mathrm{~h}$ & $61 \pm 15$ & $480 \pm 50^{c}$ & $415 \pm 43^{c}$ \\
\hline $48 \mathrm{~h}$ & $74 \pm 8$ & $422 \pm 82^{c}$ & $502 \pm 68^{c}$ \\
\hline 3 days & $68 \pm 10$ & $472 \pm 78^{c}$ & $445 \pm 53^{c}$ \\
\hline 7 days & $80 \pm 21$ & $511 \pm 64^{c}$ & $465 \pm 61^{c}$ \\
\hline \multicolumn{4}{|c|}{ Increase of body weight $(\mathrm{g})$} \\
\hline $24 \mathrm{~h}$ & $3 \pm 1$ & $3 \pm 2$ & $4 \pm 3$ \\
\hline $48 \mathrm{~h}$ & $6 \pm 2$ & $17 \pm 5^{\mathrm{a}}$ & $17 \pm 8^{\mathrm{a}}$ \\
\hline 3 days & $9 \pm 4$ & $24 \pm 6^{a}$ & $19 \pm 8^{\mathrm{a}}$ \\
\hline 7 days & $18 \pm 2$ & $29 \pm 6^{\mathrm{a}}$ & $27 \pm 4^{\mathrm{a}}$ \\
\hline 7 weeks & $54 \pm 5$ & $76 \pm 7^{\mathrm{a}}$ & - \\
\hline
\end{tabular}

Comparisons with controls, ${ }^{\mathrm{a}} p<0.05,{ }^{\mathrm{b}} p<0.01,{ }^{\mathrm{c}} p<0.001$.

Data are means $\pm \mathrm{SEM}$

Table 2. Corticosterone concentrations in plasma after $24 \mathrm{~h}$, 48 h, 3 days and 7 days of insulin exposure compared to control rats. IGF-1 concentrations in plasma after 7 days of insulin exposure

\begin{tabular}{|c|c|c|c|}
\hline & $\begin{array}{l}\text { Control } \\
(n=10)\end{array}$ & $\begin{array}{l}\text { Insulin- and pro- } \\
\text { pranolol-treated } \\
\text { rats, adrenalecto- } \\
\text { mized and sub- } \\
\text { stituted with cor- } \\
\text { ticosterone } \\
(n=9)\end{array}$ & $\begin{array}{l}\text { Insulin- and } \\
\text { propranolol- } \\
\text { treated rats } \\
(n=5)\end{array}$ \\
\hline \multicolumn{4}{|c|}{ Corticosterone (nmol/l) } \\
\hline $24 \mathrm{~h}$ & $318 \pm 45$ & $185 \pm 29^{b}$ & $450 \pm 24^{b}$ \\
\hline $48 \mathrm{~h}$ & $286 \pm 24$ & $101 \pm 14^{b}$ & $491 \pm 39^{b}$ \\
\hline 3 days & $332 \pm 18$ & $65 \pm 21^{b}$ & $398 \pm 22^{\mathrm{a}}$ \\
\hline 7 days & $299 \pm 34$ & $98 \pm 18^{\mathrm{b}}$ & $475 \pm 30^{b}$ \\
\hline \multicolumn{4}{|c|}{$I G F-I(\mu g / l)$} \\
\hline 7 days & $771 \pm 44$ & $641 \pm 42^{a}$ & $730 \pm 34$ \\
\hline
\end{tabular}

Comparisons with controls, ${ }^{\mathrm{a}} p<0.05 ;{ }^{\mathrm{b}} p<0.01$.

Data are means \pm SEM

elevation was seen after $48 \mathrm{~h}$, reaching its maximum after 3 days, and apparently decreasing after 7 days. After 7 weeks of insulin exposure there were no longer significant differences between control and insulintreated rats. Rats which were exposed to insulin, but not adrenalectomized tended to show lower values than controls, which was evident in the extensor digitorum longus at $24 \mathrm{~h}$. When all values at 24 and $48 \mathrm{~h}$ and 3 days were pooled, the insulinized group with intact adrenals showed significantly lower values than controls $(p<0.05)$. 


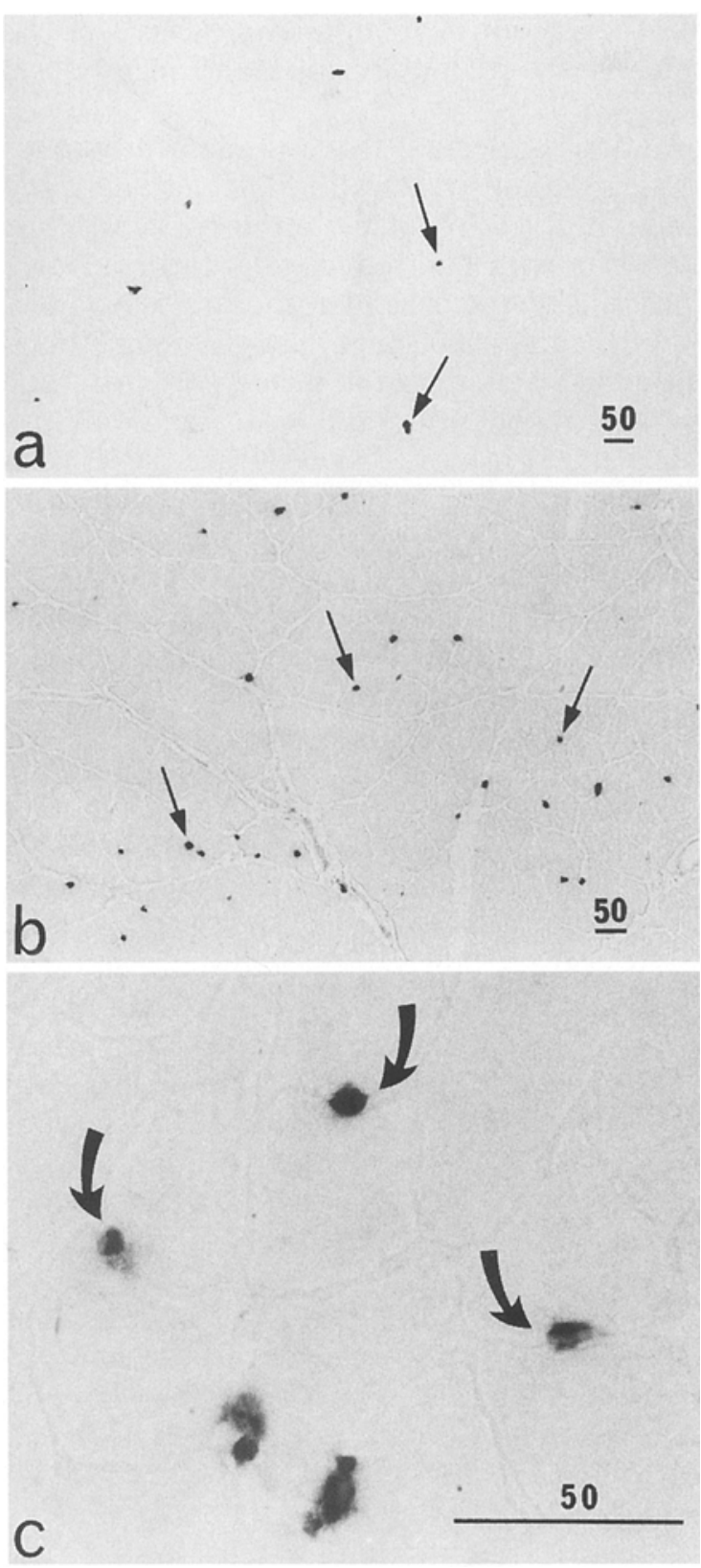

Fig. 1a-c. Sections from soleus muscle of rats processed to demonstrate BrdU incorporation. a Control rat. Comparatively few replicating cells (arrows) are seen. b Soleus muscle of a rat treated with insulin for 3 days with controlled corticosterone secretion. The number of stained cells (arrows) are increased compared to controls. c Higher magnification of $b$ ) showing localization of replicating cells to the site of capillaries between muscle fibers (arrows). Bars: $50 \mu \mathrm{m}$

Capillaries per unit surface area were significantly higher in the extensor digitorum longus muscle of the insulin-exposed rats with controlled corticosterone concentrations after 7 days compared to the control rats, but not in the soleus muscle. The increase became significant after 7 weeks of insulin exposure in both muscles (Fig. 4).

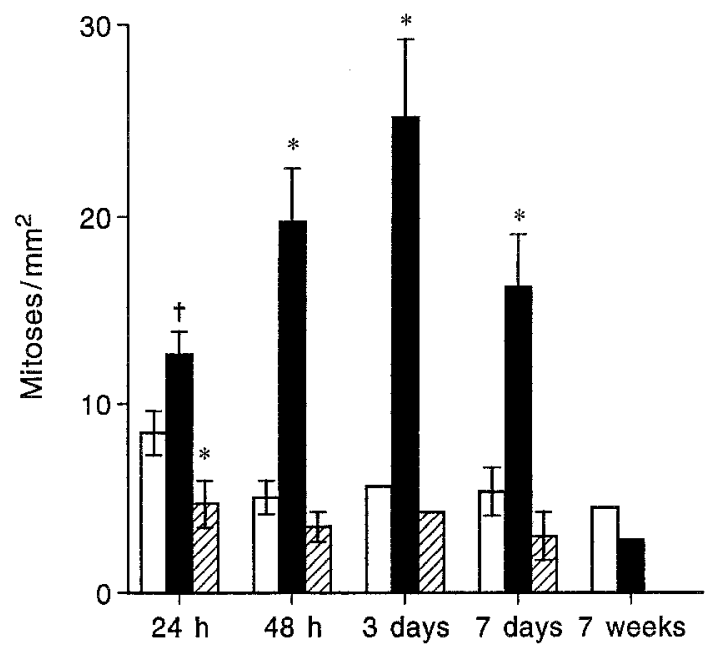

Fig. 2. Number of replicating cells in capillary endothelium in the soleus muscle observed after $24 \mathrm{~h}, 48 \mathrm{~h}, 3$ days and 7 days of insulin exposure in saline-infused control rats $(\square)$ and in rats infused with insulin, propranolol, adrenalectomized and corticosterone substituted $(\square)$ and in rats infused with insulin and propranolol ( Values represent mean \pm SEM. $(n=5-$ 10 rats. $\dagger p<0.05, * p<0.001$, comparisons with controls, ANOVA). The number of replicating cells were calculated from cryosections stained for BrdU immunohistochemistry (see Fig. 1)

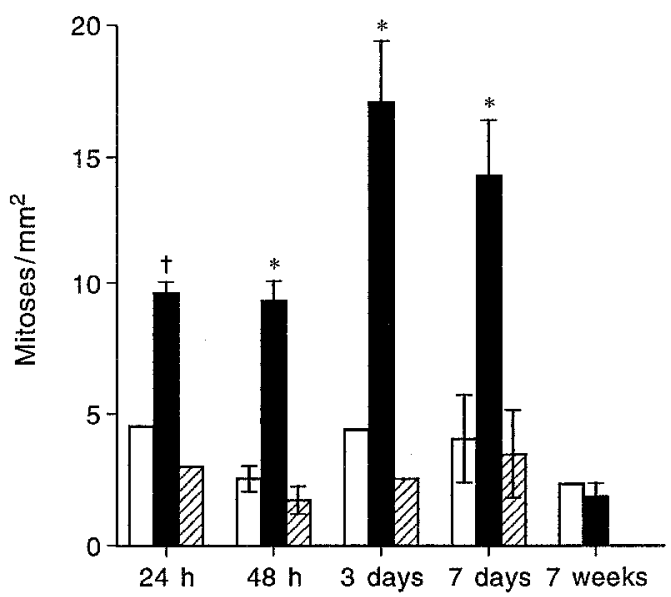

Fig. 3. Number of replicating cells in capillary endothelium in the extensor digitorum longus muscle observed after $24 \mathrm{~h}$, 48 h, 3 days and 7 days of insulin exposure in saline-infused control rats $(\square)$ and in rats infused with insulin, propranolol, adrenalectomized and corticosterone substituted $(\square)$ and in rats infused with insulin and propranolol ( Values represent mean \pm SEM. $(n=5-10$ rats. $\dagger p<0.05, * p<0.001$, ANOVA $)$. The number of replicating cells were calculated from cryosections stained for BrdU immunohistochemistry (see Fig. 1)

\section{Discussion}

Chronic exposure to moderately increased levels of insulin caused a marked but transient increase in the number of mitoses in skeletal muscle capillaries. This was followed by moderate but significant elevations in the number of capillaries, persisting after the initial stimulation of the formation of new endothelial cells. 

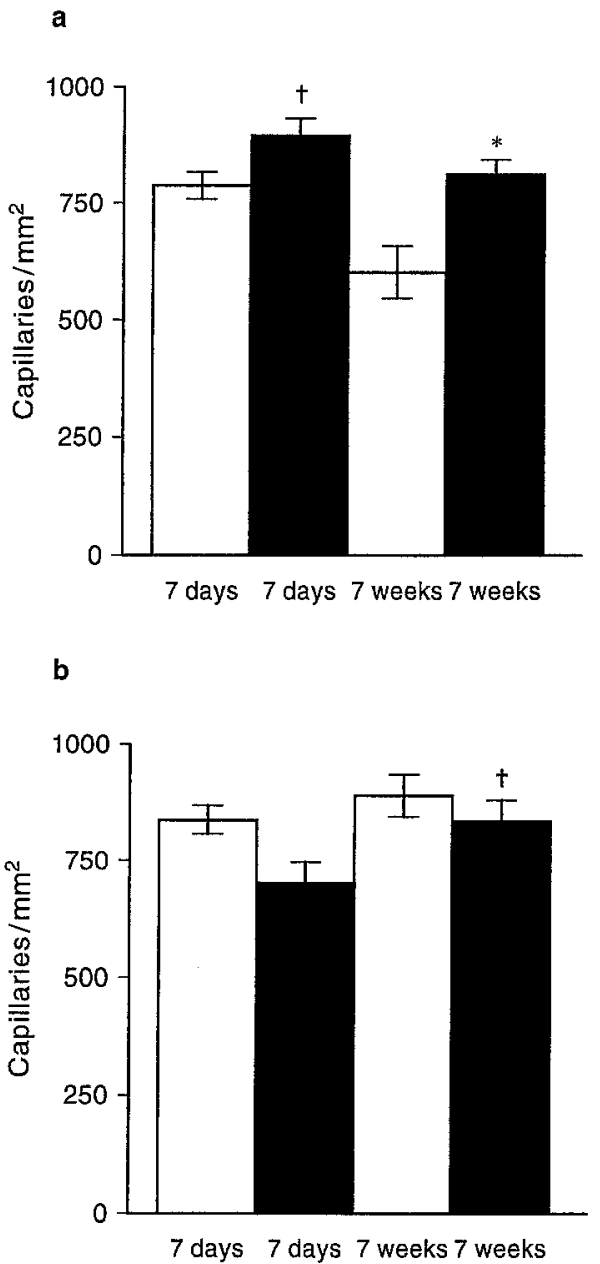

Fig. 4 a,b. Capillaries per unit surface area $\mathbf{a}$ in the extensor digitorum longus and $\mathbf{b}$ the soleus muscles of the saline-infused control rats $(\square)$ and in rats infused with insulin, propranolol, adrenalectomized and corticosterone substituted $(\square)$. Values represent means \pm SEM. $(n=5-10$ rats, $* p<0.01, \dagger p<0.05$, ANOVA)

The effect on capillary proliferation was seen only if compensatory increases in corticosterone secretion were prevented. In animals with intact adrenal glands exposed to insulin no increase in the number of mitoses occurred; instead a slight inhibition was seen. The more pronounced elevation of the rate of multiplication of endothelial cells than of capillary density suggests that insulin exposure influences the multiplication as well as the turn-over rate of these cells, the net effect being a moderately increased capillary density. This is followed by a parallel augmentation of insulin sensitivity of glucose metabolic pathways in muscle $[11,12]$.

Moderate hyperinsulinaemia, within the physiological range of insulin concentrations, was created by constant infusion through osmotic minipumps. Counter-regulatory elevation of glucocorticoid secretion was controlled by adrenalectomy and corticosterone substitution, and increased activity of the sympathetic nervous system by constant infusion of pro- pranolol. These control manipulations have no effects themselves on capillarization and metabolism [11].

We found, as expected, that the main difference between the insulinized rats with intact adrenals, and the insulinized, adrenalectomized-corticosterone substituted rats with controlled glucocorticoid concentrations, was an increase in corticosterone values. Another difference was a slight hypoglycaemia found in the insulinized, adrenalectomized-corticosterone substituted group, but not in the insulinized rats with intact adrenals. However, since similar changes in metabolism and capillarization are also found in insulinized, adrenalectomized-corticosterone substituted rats when hypoglycaemia is prevented by glucose in the drinking water $[11,12]$ it seems unlikely that hypoglycaemia should be of major importance for the effect seen on capillary proliferation.

It should be noted that control rats had significantly higher corticosterone activity than the adrenalectomized rats with glucocorticoid substitution. Substitution by this technique results in normal, physiological concentrations of corticosterone such as those seen in the corticosterone-substituted adrenalectomized rats in this study, and therefore the elevated values in the control rats were probably due to the acute interventions when the rats were killed. This assumption is supported by the observations that such rats show a normal insulin sensitivity $[11,12]$ in contrast to rats exposed to cortisol for several days [8]. However, it cannot be excluded that the elevated cortisol levels in control rats were also blunting the formation of new capillaries.

The results of the present study thus indicate that physiological levels of insulin can act as a powerful mitogen on endothelial cells in vivo. Normally insulin does not function as a growth factor in adult tissue. However, insulin acts as a growth factor in early development and during this phase probably exerts its effects through interaction with a fetal form of the IGF-I receptor [20]. Adult skeletal muscle tissue expresses both IGF-I receptors and insulin receptors, but in addition there is increasing evidence that hybrid receptors are also expressed [20-22]. These receptors are heterotetramers containing one insulin receptor with alpha and beta subunits and one IGF-I receptor with alpha and beta subunits. Both IGF-I and insulin can bind to the receptor, although normally IGF-I has a higher affinity for the receptor than does insulin [21,23]. It is possible that the mitogenic effects of insulin seen in the present study were exerted through interactions with hybrid receptors, thereby starting a growth factor signal cascade. The insulin levels used in the present study were within the physiological limits but since the counteracting hormones were controlled, the change at the receptor level could well be sufficient to affect ligand/receptor interactions. 
Taken together, the results of this study suggest that exposure to insulin in this rat model is followed by a dramatic short-term increase of the formation of new capillary endothelial cells in muscle. The discrepancy of the effects on cell multiplication and the net results of capillary density suggest that the turnover of capillary endothelial cells is also elevated. The increased multiplication induced by insulin was totally abolished in rats with intact adrenals and elevated corticosterone concentrations in circulation; instead a tendency to decrease was found. Cortisol exposure is known to be followed by diminished capillary density $[9,10]$. These observations suggest that cortisol prevents the stimulatory effects of insulin on the formation of new capillaries, implicating a balance between insulin and glucocorticoids in the regulation of muscular capillary density.

Previous work has shown a parallel between capillary density and insulin sensitivity after manipulation of concentrations of insulin and hormones with effects opposing those of insulin $[5,10,11]$. Transport of insulin from the circulation to the site of activity on the muscle cell has been considered to be rate-limiting for insulin action [13-16]. The results presented here and previously $[5,8,11]$ may therefore mean that the classical insulin-anti-insulin hormonal balance regulates the net effects on target cells in muscle, not only by modifications at insulin receptor and post-receptor levels, but also at a 'pre-receptor' level, provided by the capillary barrier to insulin translocation into the extracellular space.

Acknowledgements. The excellent laboratory assistance of Ms. B.-M. Larsson and Ms. L. Halvordsson is gratefully acknowledged. This study was supported by grants from Göteborg Medical Society, Novo Nordic Foundation and the Swedish Medical Research Council (Project No. $-19 \times-251$ and $-12 \times-$ 07120).

\section{References}

1. Reaven G (1988) Banting lecture 1988: role of insulin resistance in human disease. Diabetes 37: 1595-1607

2. Lithell H, Lindgärde F, Hellsing $\mathrm{K}$ et al. (1981) Body weight, skeletal muscle morphology and enzyme activities in relation to fasting serum insulin concentration and glucose tolerance in 48-year old men. Diabetes 30: 19-25

3. Lillioja S, Young AA, Cutler CL et al. (1987) Skeletal muscle capillary density and fibre type are possible determinants of in vivo "insulin resistance" in man. J Clin Invest 80: $415-424$

4. Lillioja S, Bogardus C (1988) Insulin resistance in Pima Indians. Acta Med Scand [Suppl] 723: 103-119

5. Holmäng A, Svedberg J, Jennische E, Björntorp P (1990) Effects of testosterone on muscle insulin sensitivity and morphology in female rats. Am J Physiol 259: E555-E560
6. Guillaume-Gentil C, Assimacopoulos-Jeannet F, Jeanrenaud B (1993) Involvement of non-esterified fatty acid oxidation in glucocorticoid-induced peripheral insulin resistance in vivo in rats. Diabetologia 36: 899-906

7. Evans P, Hoffman R, Kalkhoff R, Kissebah A (1983) Relationship of androgenic activity to body fat topography, fat cell morphology and metabolic aberrations in menopausal women. J Clin Endocrinol Metab 57: 304-310

8. Holmäng A, Björntorp P (1992) The effects of cortisol on insulin sensitivity in muscle. Acta Physiol Scand 144: 425431

9. Danneskjold-Samsoe B, Grimby G (1986) The influence of prednisolone on the muscle enzymes in patients with rheumatoid arthritis. Clin Sci 71: 693-697

10. Rebuffé-Scrive M, Krotkiewski M, Elfverson J, Björntorp $\mathrm{P}$ (1988) Muscle and adipose tissue morphology and metabolism in Cushing's syndrome. J Clin Endocrinol Metab 67: $1122-1125$

11. Holmäng A, Brzezinska Z, Björntorp P (1993) The effects of hyperinsulinemia on muscle fiber composition and capillarization in rats. Diabetes 42: 1073-1081

12. Holmäng A, Jennische E, Björntorp P (1995) The effects of long-term hyperinsulinemia on insulin sensitivity in rats. Acta Physiol Scand 153: 67-73

13. Rasio E, Mach E, Egdahl R, Herrera M (1968) Passage of insulin across vascular membranes in the dog. Diabetes 17 : $668-672$

14. Yang YJ, Hope JD, Ader M, Bergman RN (1989) Insulin transport across capillaries is rate limiting for insulin action in dogs. J Clin Inv 84: 1620-1628

15. Holmäng A, Björntorp P, Rippe B (1992) Tissue uptake of insulin and inulin in "red" and "white" skeletal muscle in vivo. Am J Physiol 263: 1171-1176

16. Castillo C, Bergman R, Thuillez P, Lillioja S (1994) Interstitial insulin concentrations determine glucose uptake rate but not insulin resistance in lean and obese man. J Clin Invest 93: 10-16

17. Bia MJ, Tyler K, DeFronzo R (1977) Regulation of extra renal potassium homeostasis by adrenal hormones in rats. Am J Physiol 233: F509-F513

18. Akana S, Cascio C, Shinsako J, Dallman M (1985) Corticosterone narrow range required for normal body and thymus weight. Am J Physiol 249: R527-R532

19. Harms G, van Goor H, Koudstaal J, de Levy L, Hardonk MJ (1986) Immunohistochemical demonstration of DNAincorporated 5-bromodeoxyuridine in frozen and plastic embedded sections. Histochemistry 85: 139-143

20. Alexandrides TK, Chen J-H, Bueno R, Giorgino F, Smith RJ (1993) Evidence for two insulin-like growth factor I receptors with distinct primary structure that are differentially expressed during development. Reg Peptides 48: 279-290

21. Moxham CP, Jacobs S (1992) Insulin/IGF-I receptor hybrids: a mechanism for increasing receptor diversity. $\mathrm{J}$ Cell Biochem 48: 136-140

22. Oh Y, Müller HL, Neely EK, Lamson G, Rosenfeld RG (1993) New concepts in insulin-like growth factor receptor physiology. Growth Regul 3: 113-123

23. Pessin JE, Frattali PM (1993) Molecular dynamics of insulin/IGF-1 receptor transmembrane signaling. Mol Reprod Dev 35: 339-345 